\title{
Ischemia modified albumin: A potential marker for global metabolic risk in genera- lized anxiety disorder and panic disorder
}

\author{
iskemi modifiye albumin: Yaygın anksiyete bozukluğu ve panik bozuklukta- \\ ki genel metabolik risk için potansiyel bir belirteç \\ Esra Kabadayi Sahin ${ }^{1}$, Gokcen Turan², Salim Neselioglu 3 , Murat Ilhan Atagun ${ }^{4}$ \\ ${ }_{1}^{1}$ M.D., Department of Psychiatry, Dr Abdurrahman Yurtaslan Ankara Oncology Research and Training Hospital, Ankara, Turkey \\ https://orcid.org/0000-0003-1320-0119 \\ 2M.D., Department of Psychiatry, Ankara City Hospital, Ankara, Turkey https://orcid.org/0000-0002-7417-2273 \\ ${ }^{3}$ Assoc. Prof., Department of Biochemistry, Ankara Yildirim Beyazit University Medical School, Ankara, Turkey \\ https://orcid.org/0000-0002-0974-5717 \\ ${ }^{4}$ Assoc. Prof., Department of Psychiatry, Ankara Yildirim Beyazit University Medical School, Ankara, Turkey \\ https://orcid.org/0000-0002-8514-0576
}

\section{SUMMARY}

Objective: Ischemia modified albumin (IMA) is an altered type of albumin produced due to exposure to hypoxia, acidosis, inflammation, or oxidative stress. In this study, we aimed to evaluate the serum IMA levels in newly diagnosed and medication-naive generalized anxiety disorder (GAD) and panic disorder (PD) patients. Method: This cross-sectional study included medicationnaive 23 GAD, 25 PD patients, and 28 healthy controls. The participants were evaluated with a sociodemographic form, the Beck Depression Inventory (BDI), and the Beck Anxiety Inventory (BAI). Venous blood samples were collected from all participants, and IMA levels and routine biochemical parameters were measured. Results: There was no statistically significant difference between three groups in terms of age, gender, body mass index (BMI) and routine biochemical markers of the participants $(p>0.05)$. The GAD and PD groups had significantly higher serum IMA levels than healthy controls $(p<0.01)$, whereas there was no statistically significant difference in IMA levels between GAD and PD groups $(p=0.994)$. Additionally, correlation analysis showed a positive correlation between IMA levels with BDI and BAI scores $(r=0.449$ and $r=0.632$, respectively, $p<0.001)$.Discussion: Higher IMA levels in patients with GAD and PD may indicate metabolic stress on these patients. Anxiety disorders may tend to various biochemical disturbances, and IMA could be an important new marker that indicates global metabolic risk in such patients. This research is the first study that evaluates IMA levels in anxiety disorders.

Key Words: Ischemia modified albumin, generalized anxiety disorder, panic disorder

\begin{abstract}
ÖZET
Amaç: İskemi modifiye albümin (IMA), hipoksi, asidoz, inflamasyon, oksidatif stres sonucu üretilen modifiye bir albümin türüdür. Bu çalışmada, yeni tanı alan ve daha önce ilaç kullanmamış yaygın anksiyete bozukluğu (YAB) ve panik bozukluk (PB) hastalarında serum iMA düzeylerinin değerlendirilmesi amaçlanmıştır. Yöntem: $\mathrm{Bu}$ kesitsel çalışmaya, daha önce ilaç kullanmamış 23 YAB, 25 PB hastası ve 28 sağlıklı kontrol dahil edildi. Katılımcılar sosyodemografik veri formu, Beck Depresyon Ölçeği (BDÖ) ve Beck Anksiyete Ölçeği (BAÖ) ile değerlendirildi. Tüm katılımcıların serum iMA düzeyleri ve rutin biyokimyasal parametreleri ölçüldü. Bulgular: Katılımcıların yaş, cinsiyet, vücut kitle indeksi (VKI) ve biyokimyasal belirteçleri açısından gruplar arasında istatistiksel olarak anlamlı fark yoktu ( $p>0.05)$. Serum iMA düzeyleri $\mathrm{YAB}$ ve $\mathrm{PB}$ gruplarında sağlıklı kontrollere göre anlamlı olarak daha yüksekken $(p<0,01)$, YAB ve PB grupları arasında iMA düzeyleri açısından istatistiksel olarak anlamlı fark yoktu $(p=0,994)$. Korelasyon analizlerinde, IMA düzeyleri ile BDÖ ve BAE puanları arasında pozitif korelasyon saptandı (sırasıyla $r=0.449$ ve $r=$ $0.632, p<0.001)$. Sonuç: YAB ve PB hastalarındaki yüksek IMA seviyeleri, bu hastalardaki metabolik stresi gösterebilir. Anksiyete bozukluklarında çeşitli biyokimyasal bozukluklar görülebilmektedir. IMA, bu hastalarda genel metabolik riski gösteren önemli bir yeni belirteç olabilir. Bu araştırma, anksiyete bozukluklarında iMA düzeylerini değerlendiren ilk çalışmadır.
\end{abstract}

Anahtar Sözcükler: İskemi modifiye albumin, yaygın anksiyete bozukluğu, panik bozukluk

(Turkish J Clinical Psychiatry 2021;24:153-159)

DOI:10.5505/kpd.2020.49404 


\section{INTRODUCTION}

Anxiety disorders are a group of psychiatric disorders defined by excessive worry, fear, and hyperarousal that cause clinically significant distress, impairment in functioning, and loss of life quality. They are among the most common psychiatric disorders with a heterogeneous spectrum of clinical manifestations and various levels of severity (1). The lifetime prevalence is estimated between 4.3$5.9 \%$ for generalized anxiety disorder (GAD) (2) and $1.1-4.7 \%$ for panic disorder (PD) (3).

Various explanations of the etiopathogenesis for the anxiety disorders emerged. Diverse social, genetic, cognitive, behavioral, and biological studies revealed that GAD and PD share heterogeneous pathophysiological mechanisms. Recently, accumulating evidence suggests that oxidative stress, inflammation and neuroendocrine abnormalities are among the critical underlying biological mechanisms in the etiopathogenesis of these disorders $(4,5)$. Metabolic stress that exceeds the capacity of the balance mechanisms may damage cellular components such as proteins, lipids, carbohydrates and nucleic acids (6) and leads to neuronal damage, which results in various diseases, including psychiatric disorders (7-9).

Ischemia modified albumin (IMA) is considered as a novel serum biomarker that implicates systemic metabolic stress in circulation (10). The N-terminus of serum albumin has the ability to bind transitional metals such as cobalt, iron, copper, and nickel and acts as a vital antioxidant and protective molecule in the blood (11). The N-terminus is prone to be modified by reactive oxygen species due to metabolic stress such as inflammation, hypoxia, acidosis, free radicals, and free iron. The albumin $\mathrm{N}$-terminus residue's damage gives rise to a reduction in its binding capacity to those metal elements (12). Serum IMA level has already been used as an important marker for myocardial ischemia (13). However, it was revealed in different studies that serum IMA levels increased not only in systemic diseases such as coronary artery disease, diabetes, obesity (14-16) but also in psychiatric disorders such as schizophrenia, bipolar disorder, and depression $(17,18)$.
To our knowledge, no study in the literature investigated the IMA levels in anxiety disorders. Besides, medications may interfere with the measurement of IMA by binding albumin molecules. Even though albumin is not directly modified by a medication, it may lose its affinity to bind cobalt ions through the indirect action of some certain medications. Therefore, in this study, we aimed to evaluate serum IMA levels in newly diagnosed and medication-naive patients with PD and GAD.

\section{METHODS}

This research is a cross-sectional, single-centered study. The patient groups consisted of 23 GAD patients and 25 PD patients who were between the ages of 18-65 years, medication-naive, and newly diagnosed according to the Diagnostic and Statistical Manual of Mental Disorders-5 (DSM-5) criteria at the psychiatry outpatient clinic of the hospital. The control group included age, gender, and body mass index (BMI) matched 28 healthy individuals who had no medical diseases or psychiatric disorders. Alcohol users, smokers, obese individuals (BMI >30), and those who had any comorbid chronic disease, psychiatric disorder, history of acute infection in the last two months, or who used any medication or herbal and vitamin supplements were excluded from the study.

In the clinical assessment, the socio-demographic data were collected with a form prepared by the researchers. The Beck Depression Inventory (BDI) and Beck Anxiety Inventory (BAI) were administered to all participants. The BDI is a 17 -item selfreport scale developed by Beck to evaluate the symptoms and severity of depression (19). The Turkish validity and reliability studies of BDI were performed (20). The BAI is a 21-item self-report scale that assesses anxiety symptoms of an individual (21). The Turkish validity and reliability study of the scale was performed by Ulusoy et al. (22). Both tests are Likert-type scales, and each item is evaluated with a score between 0 and 3 .

The study's approval was granted by the Institutional Ethics Committee (no:26379996/16, date:18.01.2017), and written informed consent was obtained from all participants before study partici- 
pation.

Measurement of biochemical and oxidative stress parameters

Venous blood samples were drawn from all participants into EDTA tubes. The blood samples were centrifuged at $1800 \mathrm{~g}$ for 10 minutes, and the obtained serum samples were stored at $-800 \mathrm{C}$ until the day of biochemical analysis. Biochemical analysis was conducted when the samples were dissolved after being kept at $+4^{\circ} \mathrm{C}$ for 12 hours. From the collected samples, hemogram, liver, kidney and thyroid function test, serum albumin and ferritin levels were measured.

Serum IMA levels were evaluated by a manual colorimetric assay described by Bar-Or et al.based on the measurement of the cobalt binding ability of the serum albumin (13). $50 \mu \mathrm{L}$ of $\% 0.1$ cobalt chloride $(\mathrm{CoCl} 2.6 \mathrm{H} 2 \mathrm{O})$ was gently added to $200 \mu \mathrm{L}$ of patient serum and waited 10 minutes in the dark to ensure adequate cobalt-albumin binding. Then 50 $\mu \mathrm{L}$ of dithiothreitol (DTT) $(1.5 \mathrm{mg} / \mathrm{mL} \mathrm{H2O})$ was added to the serum as a colorizing agent. In order to stop the chemical reaction, $1.0 \mathrm{~mL}$ of $0.9 \% \mathrm{NaCl}$ was added to the solution after two minutes. The blank tubes were prepared for each sample similarly without DTT addition. The absorbance of the solutions was measured with a spectrophotometer at $470 \mathrm{~nm}$. The IMA concentration was then obtained by the difference between the samples with and without DTT and reported in absorbance units (ABSU).

\section{Statistical analysis}

Variables were reported as means \pm standard deviations (sd) or frequencies (\%). The normally dis- tributed continuous variables were compared with the one-way ANOVA test. For multiple comparisons, post-hoc Tukey tests were used since all variances were homogeneous in the Levene's Test for Homogeneity of Variances. For the categorical variables, Pearson's chi-square test was used. Correlations between continuous variables were tested by bivariate Pearson's correlation analysis, while $\eta$ (eta) correlation coefficient was used to test the correlation between continuous and categorical variables. A priori power analysis was performed to determine sample size for detecting a difference between the groups at an effect size of $\mathrm{f}=0.40$ in IMA measurement based on the one-way ANOVA analysis $(a=0.05$, power $=0.80)$. The analyses were performed using the Statistical Package for Social Sciences 25.0 for Windows (SPSS, IBM Inc., Armonk, NY / USA). A p-value of $<0.05$ was considered statistically significant.

\section{RESULTS}

A total of $23 \mathrm{GAD}$ patients, $25 \mathrm{PD}$ patients, and 28 healthy controls were included in the study. Table 1 shows the general demographic characteristics and psychometric test scores of both patient groups and healthy controls. There was no statistically significant difference between groups in terms of age, gender, and BMI of the participants $(p>0.05)$. When BDI and BAI scores were considered, significant differences between groups were observed $(\mathrm{p}<0.001)$. Based on the post-hoc multiple comparisons tests, BDI and BAI scores of the GAD and PD groups were statistically significantly higher than the control group $(\mathrm{p}<0.001)$. However, there was no statistically significant difference between the GAD and PD groups in terms of BDI and BAI scores.

Table 1. General characteristics of patient groups and health controls

\begin{tabular}{|c|c|c|c|c|c|}
\hline & GAD (n=23) & $\mathrm{PD}(\mathrm{n}=25)$ & Control $(n=28)$ & ES : & $\mathrm{F}, \chi^{2}$ \\
\hline Age (years) ${ }^{*}$ & $30.43 \pm 6.54$ & $30.00 \pm 7.92$ & $30.43 \pm 6.13$ & 0.001 & 0.032 \\
\hline Gender, female ${ }^{\dagger}$ & $15(65.2 \%)$ & $16(66.7 \%)$ & $20(71.4 \%)$ & 0.058 & 0.253 \\
\hline BMI $(\mathrm{kg} / \mathrm{m} 2)^{\circ}$ & $23.90 \pm 3.32$ & $23.69 \pm 3.88$ & $23.76 \pm 2.69$ & 0.001 & 0.023 \\
\hline BDI score $e^{*}$ & $12.48 \pm 4.42$ & $11.29 \pm 5.79$ & $2.29 \pm 2.05$ & 0.553 & 44.62 \\
\hline BAI score ${ }^{*}$ & $24.61 \pm 6.81$ & $24.04 \pm 6.04$ & $2.54 \pm 2.13$ & 0.808 & 151.19 \\
\hline
\end{tabular}

Values are presented as mean $\pm \mathrm{sd}$, or $\mathrm{n}(\%)$. 'One-way ANOVA ${ }^{\dagger}$ Pearson's chi-square test. 'Eta-squared or Cramer's V value for effect size. GAD: Generalized Anxiety Disorder, PD: Panic Disorder, BMI: Body mass index, BDI: Beck

Depression Inventory, BAI: Beck Anxiety Inventory, ES: Effect size. 


\begin{tabular}{|c|c|c|c|c|c|c|}
\hline & GAD $(n=23)$ & $\mathrm{PD}(\mathrm{n}=25)$ & Control $(n=28)$ & ES $^{*}$ & $\mathbf{F}, x^{2}$ & p \\
\hline Creatinine (mg/dL) & $0.68 \pm 0.16$ & $0.66 \pm 0.15$ & $0.69 \pm 0.13$ & 0.006 & 0.217 & 0.806 \\
\hline Total Protein (g/dL) & $7.16 \pm 0.73$ & $7.07 \pm 0.98$ & $7.30 \pm 0.54$ & 0.016 & 0.598 & 0.553 \\
\hline Albumin $(\mathrm{g} / \mathrm{dL})$ & $4.54 \pm 0.49$ & $4.61 \pm 0.56$ & $4.63 \pm 0.32$ & 0.007 & 0.267 & 0.766 \\
\hline ALT $(U / L)$ & $13.0(11.0-18.0)$ & $13.0(10.0-20.3)$ & $12.0(9.0-18.8)$ & 0.010 & 0.771 & 0.680 \\
\hline AST (U/L) & $17.0(16.0-18.0)$ & $17.5(14.5-23.0)$ & $16.5(14.3-23.8)$ & 0.002 & 0.153 & 0.927 \\
\hline TSH (uIU/mL) & $1.93 \pm 0.81$ & $1.73 \pm 0.75$ & $1.93 \pm 0.80$ & 0.015 & 0.532 & 0.590 \\
\hline Ferritin $(\mathrm{ng} / \mathrm{mL})$ & $33.4(22.6-62.5)$ & $38.4(19.4-68.9)$ & $21.6(13.1-68.7)$ & 0.047 & 3.452 & 0.178 \\
\hline IMA (ABSU) & $77.77 \pm 8.87$ & $78.12 \pm 8.65$ & $57.80 \pm 14.56$ & 0.437 & 27.943 & $<0.001$ \\
\hline
\end{tabular}

Values are presented as means $\pm \mathrm{sd}$ or median $\left(25^{\mathrm{th}}-75^{\mathrm{th}}\right.$ percentile). "eta-squared or epsilon-squared estimate of effect size, for one-way ANOVA or Kruskal Wallis tests, respectively. GAD: Generalized Anxiety Disorder, PD: Panic

Disorder, IMA:Ischemia modified albümin, ES: Effect size, p: probability value.

The biochemical variables and IMA levels of the patient groups and healthy controls are presented in Table 2 . There was no statistically significant difference in the liver, kidney, and thyroid function tests, albumin and ferritin levels between the groups ( $p>0.05)$. When IMA levels were compared between the three groups, the post-hoc test showed that GAD and PD groups had significantly higher IMA levels than healthy controls $(p<0.001)$. Nevertheless, there was no statistically significant difference in IMA levels between the GAD and PD groups $(\mathrm{p}=0.994)$.

Further correlation analyses were conducted to evaluate the association between IMA versus age, gender, BMI, serum albumin, ferritin, BDI, and BAI scores. As shown in Table 3 and Figure 1, statistically significant positive correlations were observed between IMA levels and BDI scores $(\mathrm{r}=0.449, \mathrm{p}<0.001)$ and BAI scores $(\mathrm{r}=0.632$, $\mathrm{p}<0.001)$ (Figure 1). No other significant correlation was detected between IMA levels and other biochemical variables $(p>0.05)$.

Table 3. Covariate analysis for IMA

\begin{tabular}{lcc}
\hline & \multicolumn{2}{l}{ IMA } \\
\cline { 2 - 3 } & r or $\eta$ & $\mathrm{p}$ \\
\hline Gender & 0.054 & 0.840 \\
Age & -0.038 & 0.748 \\
BMI $\left(\mathrm{kg} / \mathrm{m}^{2}\right)$ & 0.024 & 0.838 \\
BDI score & 0.449 & $<0.001$ \\
BAI score & 0.632 & $<0.001$ \\
Albumin & -0.085 & 0.469 \\
Ferritin & -0.059 & 0.618 \\
\hline r: Pearson's correlation coefficient was \\
used for continuous variables. $\eta$ : eta \\
correlation coefficient was used for \\
categorical variables. IMA:Ischemia \\
modified albumin, BMI: Body mass \\
index, BDI:Beck Depression Inventory, \\
BAI:Beck Anxiety Inventory, p: \\
probability value.
\end{tabular}

\section{DISCUSSION}

This study revealed that GAD and PD patients had significantly higher serum IMA levels than healthy controls. In correlation analysis, serum IMA levels were correlated with the severity of anxiety in all groups. To our knowledge, this is the first study to investigate serum IMA levels in anxiety disorders.

The neurons are highly vulnerable to hypoxia, acidosis, and oxidative stress since the brain's oxygen consumption is high, and the brain has relatively limited defense mechanisms (23). The increase in oxidant load and hyperactivation of pro-inflammatory pathways trigger cellular apoptosis and cause cellular destruction and neuronal loss (4). It has been suggested that emotional stress can induce the production of reactive oxygen species (ROS) and thus cause neuroinflammation. Additionally, it is also showed that neuroinflammation and oxidative stress might contribute to anxiety-like behaviors in animal models (24).

Many studies investigating inflammation and oxidative stress in anxiety disorders showed concurrent results about the role of neuronal loss due to ROS and pro-inflammatory molecules in the pathophysiology of these disorders. It is stated that the total oxidant load is increased, and various antioxidant molecules are decreased in anxiety disorders such as GAD, PD, and social phobia (2527). In studies investigating specific oxidative stress mechanisms, it was revealed that the malondialdehyde (MDA) level, a lipid peroxidation end-product, was higher in anxiety disorders compared to healthy controls $(26,28)$. In another study, it was shown that thiol-disulphide homeostasis, which referred to thiol groups' role in albumin, glutathione, and cysteine in oxidative balance, was disrupted in GAD and PD (29). Serum xanthine oxi- 

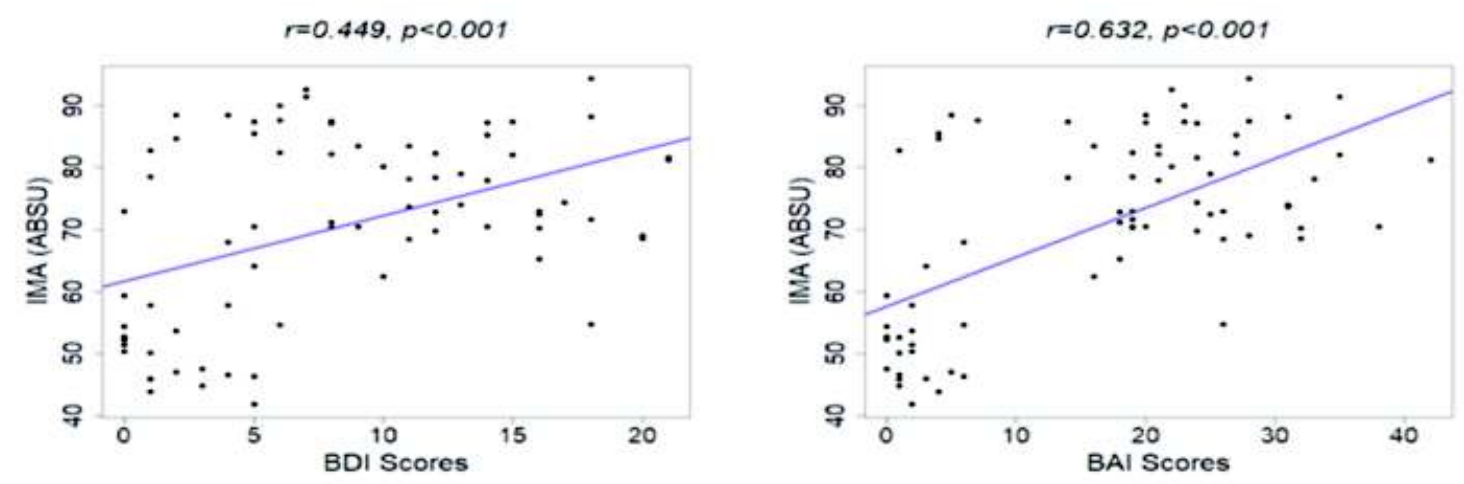

Figure 1. Partial regression plot between IMA and BDI, BAI scores.

IMA: Ischemia modifed albumin, BDI: Beck Depression Inventory, BAI: Beck Anxiety Inventory, p: probability value.

dase $(\mathrm{XO})$ and adenosine deaminase (ADA) were found to be higher in patients with PD (30). Moreover, in studies examining the inflammatory process in anxiety disorders, anxiety was found to be associated with inflammation and cellular immunity. TNF-alpha, interleukin-6 (IL-6), CRP levels were increased in anxiety disorders $(5,31)$.

Albumin is an essential protein with numerous antioxidant features. Therefore, elevated IMA levels are associated with different oxidative stress pathways and inflammatory processes. IMA is accepted as a novel biomarker that indicates hypoxia and increased free radicals (including iron, copper), inflammation, and metabolic disturbances such as dyslipidemia and hyperglycemia (16). It was proposed that increased serum IMA levels might be associated with metabolic disturbances in schizophrenia and bipolar disorder (17). In another study, it is argued that elevated IMA levels could be associated with iron-induced oxidative stress in patients with depression (18). Although there is a lack of evidence about the role of iron overload and other metabolic disorders in the pathogenesis of anxiety disorders, hypoxia and inflammation is a well-known factor that underlies the etiology of anxiety disorders.

In some animal studies, it was revealed that hypoxia induces an inflammatory process in the hippocampus and causes anxiogenic behaviors in rats (32). Production of nitric oxide (NO), known as both neurotransmitter and ROS, was linked to precipitation of anxiety-like behaviors after cerebral ischemia (33). It was also showed that a low level of oxygen causes escape behaviors in panic disorder by activating dorsal periacuaductal gray matter, a critical region that plays a role in autonomic functions and behavioral responses to threatful stimuli (34). Additionally, it was reported that healthy individuals showed anxiety-specific behaviors following a pro-inflammatory lipopolysaccharide application (35). While pro-inflammatory cytokines were accepted to induce neuroinflammation in specific brain regions, they also intensify oxidative stress and neuronal damage (36).

There was a positive correlation between IMA levels and disease severity. There are conflicting results about the correlation of biochemical markers and disease severity. While many studies did not show any correlation between anxiety levels and oxidative stress markers $(25,29,37)$, some studies identify a relationship between psychometric test scores and inflammatory markers $(18,38)$. The results of this study may suggest that emotional stress may lead to biochemical stress in the body.

The study's cross-sectional single-centered design with a relatively small sample size was the main limitation. Another limitation was that only a limited number of oxidative stress parameters were evaluated in this research. Additionally, the usage of broader evaluation tools could make the study power stronger. Since the researchers did not have SCID training at the time that the study was planned, it could not be used. Due to the outpatient clinic conditions during the study, the selfassessment tools were administered. Although basic variables including disease comorbidity, obe- 
sity, smoking, and medication or supplement use of the participants were controlled to reduce their effects on oxidative balance, some other factors such as diet, strenuous exercise, the sleep-wake cycle could not be controlled.

\section{CONCLUSION}

In conclusion, increased serum IMA levels in GAD and PD patients could be considered a mark ofglobal metabolic disorder correlated with symptom severity in anxiety disorders. Although the cause-effect relationship has yet to be clearly determined, inflammation and oxidative stress could

\section{REFERENCES}

1. Wittchen HU, Jacobi F, Rehm J, Gustavsson A, Svensson M, Jönsson B, Olesen J, Allgulander C, Alonso J, Faravelli C, Fratiglioni L. The size and burden of mental disorders and other disorders of the brain in Europe 2010. Eur Neuropsychopharmacol 2011;21:655-79.

2. Tyrer P, Baldwin D. Generalised anxiety disorder. Lancet $2006 ; 368: 2156-66$.

3. Freire R, Zugliani M, Garcia R, Nardi A. Treatment-resistant panic disorder: a systematic review. Expert Opin Pharmacother 2016;17:159-68.

4. Bouayed J, Rammal H, Soulimani R. Oxidative stress and anxiety: relationship and cellular pathways. Oxid Med Cell Longev 2009;2:63-7.

5. Vogelzangs N, Beekman A, De Jonge P, Penninx B. Anxiety disorders and inflammation in a large adult cohort. Transl Psychiatry 2013;3:249.

6. Liguori I, Russo G, Curcio F, Bulli G, Aran L, Della-Morte D, Gargiulo G, Testa G, Cacciatore F, Bonaduce D, Abete P. Oxidative stress, aging, and diseases. Clin Interv Aging 2018;13:757.

7. Reyazuddin M, Azmi S, Islam N, Rizvi A. Oxidative stress and level of antioxidant enzymes in drug-naive schizophrenics. Indian J Psychiatry 2014;56:344.

8. Smaga I, Niedzielska E, Gawlik M, Moniczewski A, Krzek J, Pera J, Filip M. Pharmacological Reports Oxidative stress as an etiological factor and a potential treatment target of psychiatric disorders . Part 2 . Depression, anxiety, schizophrenia and autism. Pharmacol reports 2015;67:569-80.

9. Savas H, Gergerlioglu H, Armutcu F, Herken H, Yilmaz H, Kocoglu E. Elevated serum nitric oxide and superoxide dismutase in euthymic bipolar patients: impact of past episodes. World J Biol Psychiatry 2006;7:51-5.

10. Sbarouni E, Georgiadou P, Voudris V. Ischemia modified albumin changes - review and clinical implications. Clin Chem Lab Med 2011;49:177-84.

11. Bar-Or D, Curtis G, Rao N, Bampos N, Lau E. Characterization of the $\mathrm{Co}(2+)$ and $\mathrm{Ni}(2+)$ binding amino-acid residues of the $\mathrm{N}$-terminus of human albumin. Eur J Biochem. mediate critical biochemical changes in the neurons, which lead to anxiety and anxiety-specific behaviors.Further studies may be designed to evaluate which immunologic and inflammatory pathways are correlated explicitly with serum IMA levels in anxiety disorders.

Correspondence address: M.D., Esra Sahin Kabadayi, Dr Abdurrahman Yurtaslan Ankara Oncology Research and Training Hospital, Ankara, Turkey ekabadayi06@gmail.com

12. Roy D, Quiles J, Gaze D, Collinson P, Kaski J, Baxter G. Role of reactive oxygen species on the formation of the novel diagnostic marker ischaemia modified albumin. Heart 2006;92:113-4.

13. Bar-Or D, Lau E, Winkler J. A novel assay for cobalt-albumin binding and its potential as a marker for myocardial ischemia-a preliminary report. J Emerg Med 2000;19:311-5.

14. Turan T, Akyüz A, Sahin S, Kul S, Yilmaz A, Kara F, Mentese SO, Aykan AÇ, Demir SE, Celik S, Karahan SC. Association between the plasma levels of IMA and coronary atherosclerotic plaque burden and ischemic burden in early phase of non-ST-segment-elevation acute coronary syndromes. Eur Rev Med Pharmacol Sci 2017;21:576-83.

15. Kaefer M, Piva S, De Carvalho J, Da Silva D, Becker A, Coelho A, Duarte MM, Moresco RN.. Association between ischemia modified albumin, inflammation and hyperglycemia in type 2 diabetes mellitus. Clin Biochem 2010;43:450-4.

16. Ates E, Set T, Karahan S, Bicer C, Erel O. Thiol/disulphide homeostasis, ischemia modified albumin, and ferroxidase as oxidative stress markers in women with obesity with insulin resistance. J Med Biochem 2019;38:445-51.

17. Tunc S, Atagun M, Neselioglu S, Bilgin Y, Basbug H, Erel O. Ischemia-modified albumin: a unique marker of global metabolic risk in schizophrenia and mood disorders. Psychiat Clin Psych 2019;29:123-9.

18. Karasalan O, Hacımusalar Y, Amuk O, Bal C. Evaluation of ischemia modified albumin levels in major depression patients. J Surg Med 2019;3:557-60.

19. Beck A. An inventory for measuring depression. Arch Gen Psychiatry 1961;4:561-71.

20. Hisli N. A study on the validity of the Beck depression inventory. Turk Psychol J 1998;6:118-123.

21. Beck A, Epstein N, Brown G, Ster R. An Inventory for measuring clinical anxiety: psychometric properties. J Consult Clin Phychol 1988;56:893-7.

22. Ulusoy M, Sahin N, Erkmen H. Turkish version of the Beck 
Anxiety Inventory: Psychometric properties. J Cogn Psychother 1998;12:163-72.

23. Halliwell B. Oxidative stress and neurodegeneration: where are we now? J Neurochem 2006;97:1634-58.

24. Gingrich J. Oxidative stress is the new stress. Nat Med. 2005;11:1281-2.

25. Emhan A, Selek S, Bayazıt H, Karababa I, Katı M, Aksoy N. Evaluation of oxidative and antioxidative parameters in generalized anxiety disorder. Psychiatry Res 2015;230:806-10.

26. Atmaca M, Kuloglu M, Tezcan E, Ustundag B. Antioxidant enzyme and malondialdehyde levels in patients with social phobia. Psychiatry Res 2008;159:95-100.

27. Gautam M, Agrawal M, Gautam M, Sharma P, Gautam A, Gautam S. Role of antioxidants in generalised anxiety disorder and depression. Indian J Psychiatry 2012;54:244.

28. Bulut M, Selek S, Bez Y, Karababa I, Kaya M, Gunes M, Emhan A, Aksoy N, Sir A. Reduced PON1 enzymatic activity and increased lipid hydroperoxide levels that point out oxidative stress in generalized anxiety disorder. J Affect Disord 2013;150:829-33.

29. Kabadayi Sahin E, Turan G, Neselioglu S, Can S, Atagun M. Thiol-disulphide homeostasis in patients with general anxiety disorder and panic disorder. Dusunen Adam J Psychiatry Neurol Sci 2019;32:289.

30. Herken H, Akyol O, Yilmaz H, Tutkun H, Savas H, Ozen M, Kalenderoglu A, Gulec M. Nitric oxide, adenosine deaminase, xanthine oxidase and superoxide dismutase in patients with panic disorder: alterations by antidepressant treatment. Hum Psychopharmacol Clin Exp 2006;21:53-9.

31. O’Donovan A, Hughes B, Slavich G, Lynch L, Cronin M, O'Farrelly C, Malone KM. Clinical anxiety, cortisol and interleukin-6: Evidence for specificity in emotion-biology relationships. Brain Behav Immun 2010;24:1074-7.

32. Fan J, Fan X, Li Y, Guo J, Xia D, Ding L, Zheng Q, Wang W, Xue F, Chen R, Liu S. Blunted inflammation mediated by NF-KB activation in hippocampus alleviates chronic normobaric hypoxia-induced anxiety-like behavior in rats. Brain Res Bull 2016;122:54-61.

33. Nakashima M, Ajiki K, Nakashima K, Takahashi M. Possible role of nitric oxide in anxiety following transient cerebral ischemia in mice. J Pharmacol Sci 2003;91:47-52.

34. Fernandes G, Frias A, Spiacci Jr A, Pinheiro L, TanusSantos, JE Zangrossi Jr H. Nitric oxide in the dorsal periaqueductal gray mediates the panic-like escape response evoked by exposure to hypoxia. Prog Neuro-Psychopharmacology Biol Psychiatry 2019;92:321-7.

35. Reichenberg A, Yirmiya R, Schuld A, Kraus T, Haack M, Morag A, Pollmächer T. Cytokine-associated emotional and cognitive disturbances in humans. Arch Gen Psychiatry 2001;58:445-52.

36. Salim S, Asghar M, Taneja M, Hovatta I, Chugh G, Vollert $\mathrm{C}, \mathrm{Vu}$ A. Potential contribution of oxidative stress and inflammation to anxiety and hypertension. Brain Res 2011;1404:63-71.

37. Asoglu M, Kilicaslan F, Beginoglu O, Fedai U, Akil O, Celik $\mathrm{H}$, Buyukaslan H. Thiol/disulphide homeostasis as a new oxida- tive stress marker in untreated patients with generalized anxiety disorder. Anatol J Psychiatry 2018;19(2):143-9.

38. Arranz L, Guayerbas N, De la Fuente M. Impairment of several immune functions in anxious women. J Psychosom Res 2007;62:1-8. 